\title{
The Translator's Style
}

Aditi Ghosh*

Style in literature' - the 'style' of literary texts -has been the focus of many a discourse, quite understandably. The style reflected in a particular piece of writing (whatever the form of writing may be) tells us about the author, and is, in many cases, identified as his/her style. Why then is the style of a translated text not considered as the translator's style? The reasons are several:

(1) The translator's job is to present the style of the original author, and not to create a style of his own.

(2) The translation should read like an original, and thereby the translator's identity is supposed to be shrouded in the dark.

(3)Nida's contribution to Translation Studies is by no means regarded insignificant. In his opinion, the translated text should produce the same effect on the receptor audience as the original text has on the source language audience. This being the case, Nida suggests that changes be made in order to produce this effect.

(4) In more cases than not, the translated work is not evaluatedcompared with the original-to understand to what extent it resembles the original work.

What the translator does, or should do, is to get transformed into the author of the original and with all his/her mind, will and soul, and also ponder the problem of how to transform the shape, gait, style and all other features, and how to express them. The purpose is to make something written in one language well represented in another.

\footnotetext{
* Aditi Ghosh is a research scholar doing a $\mathrm{PhD}$ on Computational Lexicography at the Centre for Applied Linguistics and Translation Studies, University of Hyderabad, Hyderabad 500046. She is reachable at aditiphd@yahoo.com
}

Translation Today Volume (1) No (1) Mar. 2004 C CIIL 2004. 
The translator's job thus is accompanied by an enormous responsibility, and also runs a lot of risk. In the process, he/she falls, as Newmark points out, 'a victim of a constant tension between the acts of overtranslation and undertranslation'.

There is also the eternally pervasive question of 'fidelity' of the translator.

As a practicing translator, I have experienced /arrived at a few points:

(1)The stylistic outfit of the original text is a result/final product of the interweaving of all the kinds of elements used in it-words, phrases and so on. That is to say, the style of the original text consists in the pattern in which the words, sentences, phrases, etc., are arranged.

(2) The use of literary devices such as metaphors, similes, idioms and so on, contribute to this 'style'.

(3) In Mohanty's Harijana, the author 'style' is distinct. The various aspects of this style and its reasons will be delineated further down in this paper.

Certainly, style denotes, connotes, and leads to innumerable other ideas, points and so on, that fastidious students and stalwarts of literary stylistic analysis and discourse have already outlined in their volumes. My intention in the above said three points is not to sum up such expert notions of style; I have merely tried to express in the simplest terms what the style of the original text means to me, insofar as any discourse in translation is concerned.

This being the case does the efficient translator not try to convert the original text into another text in a different language, which should read exactly like an original text in that language, though it is not the same? The translator's task is, then, to take the content of a certain mould, and place it in another, so prudently and perhaps 'diplomatically', that it is not distorted even to the slightest extent, and at the same time, undergoes a few changes to get accommodated in its new mould, thereby producing the impression of being an original text on the mind of the intended audience. This 'prudent carrying over' of content, we at times fail to realize, 
involves a good deal of creative energy. One may ask here-how? I shall explicate this question further in this paper.

I shall first present a number of illustrations to explain how I have been obliged to make changes in Mohanty's 'style' while translating Harijana into English.

1. This novel focuses parallelly on the life of scavengers and that of people of the so-called 'high-society'. The characters in the scavengers' slum, however, form the main body of it. It concentrates on the miserable life led by scavengers, and zeroes in on the poor vis-à-vis the rich. The poor and downtrodden, represented by the scavengers, are far less opportune when compared with the rich, capitalist class signified by the two well-to-do families in the town, who dwell in a chic atmosphere. The language used by the uneducated scavengers, thus, differs from the standard version of the Oriya language, generally used by the above said richer class. The language used by the former consists of more slang, phrases and idioms than that of the latter. One example of this is the following:

The scavengers here use a lot of idiomatic expressions in their speech. While translating these, I had three options-to omit these altogether, to translate them into plain sentences and to find a corresponding idiom in English. The first option I ruled out in almost all cases because that may lead to taking away from the content. There have been some cases where a gap seemed to exist; the idiomatic phrase/sentence did not have an exactly corresponding one-an equivalent-in English. In such cases, how could that unit of expression containing that particular idiom, be transferred into the receptor language, its content remaining undisturbed? The solution I adapted was this: the content of that phrase/sentence was picked and was embedded into another sentence-in the receptor language-the form of which was as close as possible to the original.

Oriya example: to munDa ganDi paRigalA

Gloss: Your head body fell

Translation: Oh! Nothing, you fool! 
The phrase munDa ganDi is a peculiar idiomatic expression in Oriya. It is used in cases where one intends to dismiss someone's ideas or words, or does not want to take it into consideration, and intends to laugh it away, in ridicule. However, in the context in which it appears in the novel, it only serves to add to the intensity of the meaning. Apart from this it plays no other role in the expression of the meaning. Therefore in order to retain the functionality of the phrase, it has been translated keeping in mind the way in which it contributes to the effect of the sentence(s)/context it is connected with or is part of. It has thus been translated as "Oh! Nothing, you fool!"

Oriya example: ilo mo dau

Gloss: oh my ----

Translation: Oh gosh!

In this case, the phrase shows a strong colloquial tinge. And understandable, the Oriya and English colloquy are far distanced from each other, both in terms of content, and in terms of rules and technique. Not only in English, but even any other non-Oriya speakers cannot be expected to understand the exact meaning of ilo mo dau !, unless its content is taken, reconstructed in the form of an English sentence which produces the same effect in the given context, as ilo mo dau ! did, that is, serves the function of this sentence.

The creativity of the translator thus, finds utmost expression in such a case, as he/she had to 'create' a new mould-a new cast-for the content of the original.

In a case where the idiom did have an exact or at least a close equivalent, in the task was easier. The translator-creator had to, anyway, interpret an expression and recreate it in another existing form. The following is a relevant example.

Oriya ex: mana bujhe nAhi rANi o candrakANira bhedAbheda

Gloss: heart understands not queen and one-eyed's difference 
Trans: The heart does not understand the difference between Heaven and hell.

What rANi o candrakANira bhedAbheda means to an Oriya speaker, 'the difference between Heaven and hell' means to the English speaker. Therefore the phrase has been used as the equivalent for rANi o candrakANira bhedAbheda.

Nida's model of translation, which is as follows,

Source Language Text

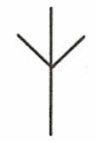

Analysis

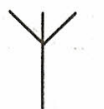

Receptor Language Translation

Transfer

Restructuring

is, I believe, a statement of the translator's creative potential.

2. Another kind of problem was posed by the author's unique/peculiar/singular technique of changing the tense of the sentences. He maintains no consistency with regard to tenses, switching frequently between past perfect, . past continuous and present perfect, etc., even while talking about the same event, or about more than one corresponding events.

One of the paragraphs in Chapter 7 of the book begins with the following sentence.

Oriya ex: $e$ tAku nuA

Gloss: this to her new

Trans: It was new to her.

The tense used in this sentence is present perfect.

The following sentence is given below.

Oriya ex: tAra

Gloss: her buddhi

thinking
hajijAe

is lost

Trans: Her thinking would be diminished. 
This sentence is set in the present continuous tense.

But the translator has converted all the sentences into the past continuous tense, for maintaining consistency in the translated text. The purpose is to avoid confusion that may otherwise have faced the target language audience.

In such cases, the translator's creative instinct predicted that if such inconsistency were maintained even in the translated version, the intended audience might either find it incomprehensible or confusing, or it might seem to them a thoroughly artificial piece of writing-a consequence that goes against the very purpose of the act translating.

The translator had no option, thus, but to standardize the tense factor. The novel starts with the past continuous tense, and that was adopted as the tense of the narration in the translated version. However, wherever the tense needed to be changed as per the requirement of the text, it has been materialized.

The style of the author has thus been somewhat altered'recreated'-to some extent, the interest of the receptor audience, so that to that group of men, the translated version reads like an original text in the language they speak.

3. The next issue worth dwelling upon consists of the problems posed by incomplete sentences. The abundant use of incomplete/broken sentences seems to be a favourite technique with Mohanty in his Harijana. There are two kinds of instances, in such cases, that the translator came across.

a. There were a number of broken /incomplete sentences which could be safely translated into English without actually opposing the grammatical set-up if the English language. A translated text should, after all, also assume a legitimate 
grammatical form in the receptor language. [Perhaps one could concede this as a case of 'poetic license'.]

Many of these incomplete sentences, when rendered into English as they were, read terribly incorrect in terms of grammar. Following is an instance of the same. In the original sentence, there was no verb. To render the translated sentence (in English) complete, the appropriate verb was added to the sentence.

Oriya ex: Agare lucA mada dokAnara hAu hAu Gloss: ahead hidden liquor shop's noise noise Translation: Ahead lies the noisy crowd of the illegal/nonlicensed liquor shop.

Let me illustrate one more of this kind.

Oriya example: pache pache gARibAlAra haT haT Gloss: following following driver's shoo shoo Translation: Following him is the driver's "shoo, shoo".

In the above example, the verb 'is' has been added to make the sentence complete.

b. There is another problem, particularly at the syntactic level that faced the translator. We shall see what they were and how they were solved.

The syntactic structure of the Oriya language follows the SubjectObject-Verb order. But in certain cases, the order has been changed to Subject-Verb-Object, or even Object-Verb-Subject, and so on, for stylistic variation wherever required, in the original. In the translated text, the syntactic order of the original has been maintained as far as possible. But there have been cases where maintaining the same order has posed a threat to the comprehensibility of the translated sentence. In such cases, the word order of the original sentences has been changed so as to fit the syntactic order of the receptor language. Here is an example.

Oriya example: dehare

jor

thiba

bahut

Gloss:

in the body strength must be a lot

Translation: There must be a lot of strength in his body. /He must be very strong. 
c. Proverbs used in the original novel have also called for considerable decision-making ability. I shall illustrate how they have been re-presented in the translated text.

Oriya example: sAta cakuLi cauda ce
Gloss: seven rice-flour cakes fourteen sound
Translation: Umm...nice food is being cooked!

In the above case, the proverb, as in many others, has a story associated with it, which is not, obviously, known to the non-Oriya speakers. Since it does not have an exact or even a close equivalent in the target language, it was translated only in terms of its content.

This is only illustrative, one could multiply examples.

In such cases, thus, the translator has had to intervene, exercise what we might call the translatorial discretion, and make the necessary changes. The style of the original text thus did not remain intact. The translator had to alter it, for obvious reasons. What finally emerged on the translated pages reflects the style of the translator-the style of the original recreated/reformatted with the intervention of he translator. It may be expressed as the following:

The style of the original + the translator's creative potential = The translator's style.

I have thus arrived at the conclusion that the 'style' of the translator reflected in the translated work, is the translator's style, not that of the author of the original. That style may be summarily defined as the following:

The style of the original author (as reflected in the SL text) + the intervention of the translated work, is the translator with skills, instinct and discretion = the translator's style (the style of the translated text).

The style of the translator's style is more like a looking glass. It consists in the translator's placing a transparent layer/sheet over the original text through which the target reader peeps and finds an original text, belonging, content-wise, to a different language and culture, but formally entirely to his own language. 


\section{References}

Nida, E.A. and C.R. Taber 1969 The Theory and Practice of Translation, Leidon: E.J. Brill.

- Newmark, P. 1981 Approaches to Translation, Oxford and New York: Pergamon. 